\title{
A NEW SPECIES OF ORIBATID MITES OF THE GENUS GALUMNA FROM SOUTH AFRICA
}

\author{
Sergey G. Ermilov ${ }^{1 *}$ and Elizabeth A. Hugo-Coetzee ${ }^{2,3}$ \\ ${ }^{1} \mathrm{X}$-BIO Institute, Tyumen State University, Tyumen, Russia \\ ${ }^{2}$ Terrestrial Invertebrates Department, National Museum, Bloemfontein, South Africa \\ ${ }^{3}$ Department of Zoology and Entomology, University of the Free State, Bloemfontein, South Africa \\ "corresponding author; e-mail: ermilovacari@yandex.ru
}

\begin{abstract}
A new oribatid mite species of the genus Galumna (Oribatida, Galumnidae) is described from South Africa, based on museum collection material. Galumna (Galumna) paralawrencei sp.n. differs from Galumna (Galumna) lawrencei Jacot, 1940 by the larger body size, the localization of adanal lyrifissures, and the presence of a hump-like structure in the anterior part of the prodorsum and distinctly longer notogastral porose areas $A a, A 2, A 3$ and anal and adanal setae.
\end{abstract}

KEY WORDS: Galumnid mites, systematics, morphology, Ethiopian region.

DOI: 10.21684/0132-8077-2020-28-1-17-22

\section{INTRODUCTION}

During our taxonomic identification of oribatid mites of the family Galumnidae (Acari, Oribatida) from the Acarology collection of the National Museum Bloemfontein (Bloemfontein, South Africa), we found one new species of Galumna Heyden, 1826 . The specimens were wrongly identified as Galumna capensis dissimilis Engelbrecht, 1969 (at present: Galumna (Galumna) lawrencei Jacot, 1940 (= Galumna (Galumna) capensis dissimilis Engelbrecht, 1969; see Ermilov and Hugo-Coetzee 2020). The main goal of the paper is to describe and illustrate this new species under the name Galumna (Galumna) paralawrencei sp.n.

Galumna was described by Heyden (1826), with Notaspis alatus Hermann, 1804 as type species. This nominative subgenus comprises more than 190 species that, collectively, have a cosmopolitan distribution (Subías 2020). As of now, 12 Galumna species have been described from South Africa: G. barnardi (Jacot, 1940); G. lawrencei Jacot, 1940; G. natalensis Jacot 1940; G. discifera Balogh, 1960; G. capensis Engelbrecht, 1969; G. dimidiata Engelbrecht, 1969; G. tricuspidata Engelbrecht, 1969; G. comparibilis Engelbrecht, 1972; G. nuda Engelbrecht, 1972; G. chrisengelbrechti Ermilov and Klimov, 2017; G. curvifamulus Ermilov, Hugo-Coetzee, Khaustov and Theron, 2017; G. sphagni Ermilov, Hugo-Coetzee and Theron, 2018 (see Jacot 1940; Balogh 1960; Engelbrecht 1969, 1972; Ermilov and Klimov 2017; Ermilov et al. 2017, 2018, Ermilov and HugoCoetzee 2019, 2020). The diagnosis of Galumna (Galumna) was presented by Ermilov and Klimov (2017). The identification key for the species of the Ethiopian region as well the Galumna species' distributional data for South Africa have previously been published by Ermilov et al. (2018).

\section{MATERIALS AND METHODS}

The specimens were mounted in lactic acid on temporary cavity slides for measurement and illustration. The body length was measured in lateral view, from the tip of the rostrum to the posterior edge of the notogaster. The notogastral width refers to the maximum width of the notogaster in dorsal view. All body measurements are presented in micrometers $(\mu \mathrm{m})$. The formulas for leg setation are provided in parentheses according to the sequence trochanter-femur-genu-tibia-tarsus (famulus included). The formulas for leg solenidia are given in square brackets according to the sequence genu-tibia-tarsus.

The drawings were made with a camera lucida using a Leica transmission light microscope "Leica DM 2500".

Morphological terminology used in this paper follows that of F. Grandjean (see Ermilov and Klimov 2017 for review and application).

The following abbreviations are used: $h l_{s-}$ hump-like structure; $L$-lamellar line; $S$ - sublamellar line; $N$-prodorsal leg niche; $E, T$-lateral ridges of prodorsum; ro, le, in, $b s$ - rostral, lamellar, interlamellar and bothridial setae, respectively; bo - bothridium; $A d$ - sejugal porose area; $D$ — dorsophragma; $P$-pleurophragma; $c, l a, l m, l p, h, p$-notogastral setal alveoli; $A a, A l, A 2, A 3$ - notogastral porose areas; $m p$-median pore; $i a$, im, ip, ih, ips-notogastral lyrifissures; gla — opisthonotal gland opening; $a, m, h$-subcapitular setae; or - adoral seta; as - axillary saccule; $c h a, c h b$ - cheliceral setae; $T g$-Trä- 

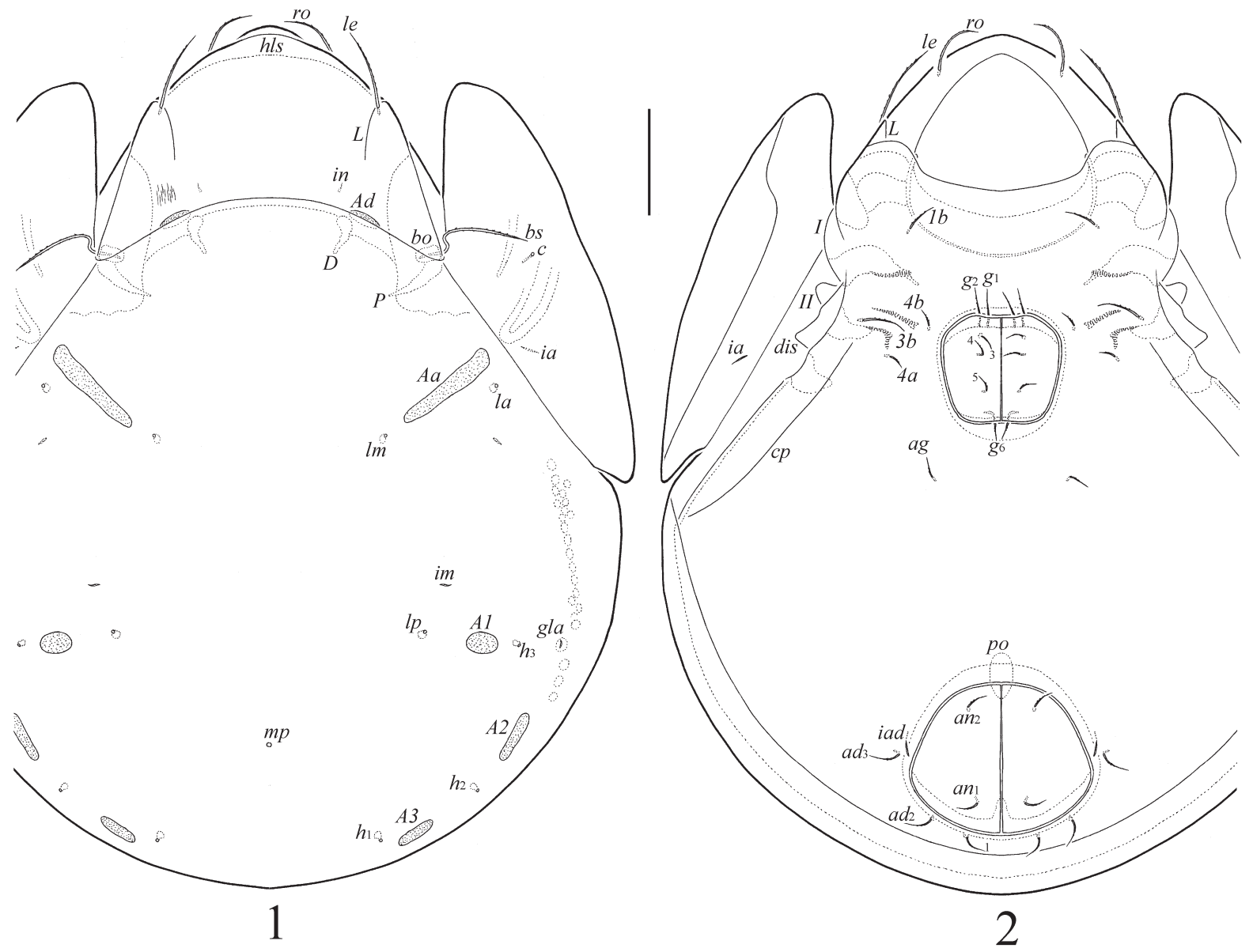

Figs. 1-2. Galumna (Galumna) paralawrencei sp.n., adult: 1-dorsal view; 2-ventral view (not shown: gnathosoma and legs). Scale bar $=100 \mu \mathrm{m}$.

gårdh's organ; $I, I I$ - pedotecta I, II, respectively; $1 b$, $3 b, 4 a, 4 b$ - epimeral setae; dis-discidium; $c p$ circumpedal carina; $g, a g$, an, ad — genital, aggenital, anal and adanal setae, respectively; iad - adanal lyrifissure; $A p$ - postanal porose area; $p o$ - preanal organ; $\mathrm{Tr}, \mathrm{Fe}, \mathrm{Ge}, \mathrm{Ti}, \mathrm{Ta}$ - leg trochanter, femur, genu, tibia, tarsus, respectively; $p a$-porose area; $\omega, \sigma$, $\varphi$ - leg solenidia; $\varepsilon$ - leg famulus; $v, e v, b v, l, d, f t$, tc, it, $p, u, a, s, p v, p l$ - leg setae.

\section{SYSTEMATICS}

Superfamily Galumnoidea

Family Galumnidae

Genus Galumna Heyden, 1826

Subgenus Galumna (Galumna) Heyden, 1826

Type species: Notaspis alatus Hermann, 1804

\section{Galumna (Galumna) paralawrencei Ermilov and Hugo-Coetzee, sp.n.}

(Figs. 1-11)

Diagnosis. Body size: 780-830×581-647. Rostrum rounded. Anterior part of prodorsum hump- like. Lamellar and sublamellar lines long, parallel, curving backwards, $L$ broad, $S$ thin. Rostral, lamellar and bothridial setae long, setiform, barbed. Interlamellar setae minute. Dorsosejugal porose areas, median pore and oval postanal porose area present. Four pairs of notogastral porose areas: $A a$ transversely elongate, slightly triangular, $A 1$ oval, $A 2$ and $A 3$ elongate oval. Epimeral and anogenital setae setiform, barbed. Adanal lyrifissures located diagonal to posterior half of anal plates. Solenidion on leg tibiae IV inserted in anterior part of the segment.

Description. Measurements. Body length: 813 (holotype, male), 780-830 (three paratypes, two males and one female); notogaster width: 614 (holotype), 581-647 (three paratypes).

Integument. Body color brown. Body surface punctate (visible under high magnification, $\times 1,000$ ). Laterobasal parts of prodorsum slightly striate.

Prodorsum (Figs. 1, 3). Rostrum rounded. Anterior part of prodorsum with large hump-like structure (distinctly visible in lateral view). Lamellar and sublamellar lines long, parallel, curving 

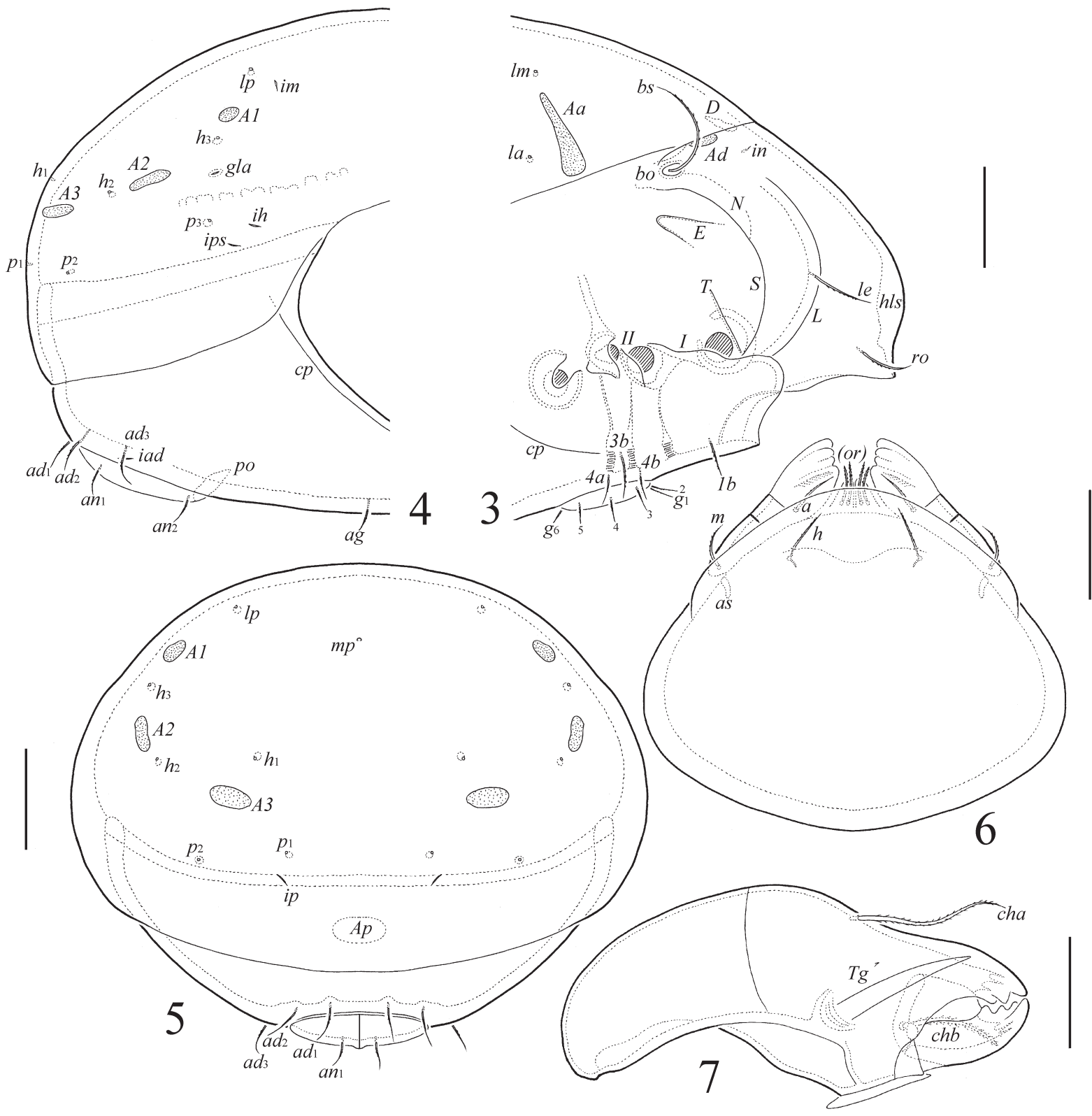

Figs. 3-7. Galumna (Galumna) paralawrencei sp.n., adult: 3 - anterior part of body, lateral view (not shown: gnathosoma, pteromorph and legs); 4- posterior part of body, lateral view; 5-posterior view; 6-subcapitulum, ventral view; 7 -chelicera, left, paraxial view. Scale bars $=100 \mu \mathrm{m}(3-5), 50 \mu \mathrm{m}(6,7)$.

backwards, $L$ comparatively broad (thickened), $S$ thin. Lateral structures $N$ and ridges $E$ and $T$ welldeveloped. Rostral (65-73) and lamellar (77-86) setae setiform, barbed. Interlamellar setae (2-4) setiform, thin, smooth. Bothridial setae (110-123) setiform, barbed. Exobothridial setae and their alveoli absent. Dorsosejugal porose areas (32$36 \times 10-12$ ) elongate oval, transversely oriented, located posterolateral to interlamellar setae. Dorsophragmata distinctly elongated longitudinally.

Notogaster (Figs. 1, 3-5). Dorsosejugal suture complete, convex medially. With 10 pairs of setal alveoli and four pairs of porose areas; $A a$ trans- versely elongate, slightly triangular (length 106 123), Al oval (24-41×16-24), A2 (53-73×16-24) and $A 3(45-61 \times 16-24)$ elongate oval. Porose areas $A a$ located close to pteromorphal hinges, anterior to setal alveoli la. Median pore present in both sexes, located between $A 2$. Opisthonotal gland openings and all lyrifissures distinct; gla located lateral to $A l$ and removed from them, im between $A a$ and $A 1$ (clearly closer to $A 1$ ), ip posterior or posterolateral to $p_{1}$, ih and ips located close to each other, anterior to $p_{3}$.

Gnathosoma (Figs. 6, 7). Size of subcapitulum: 172-176×160-168. Subcapitular $(a, 28-32 ; m$, 


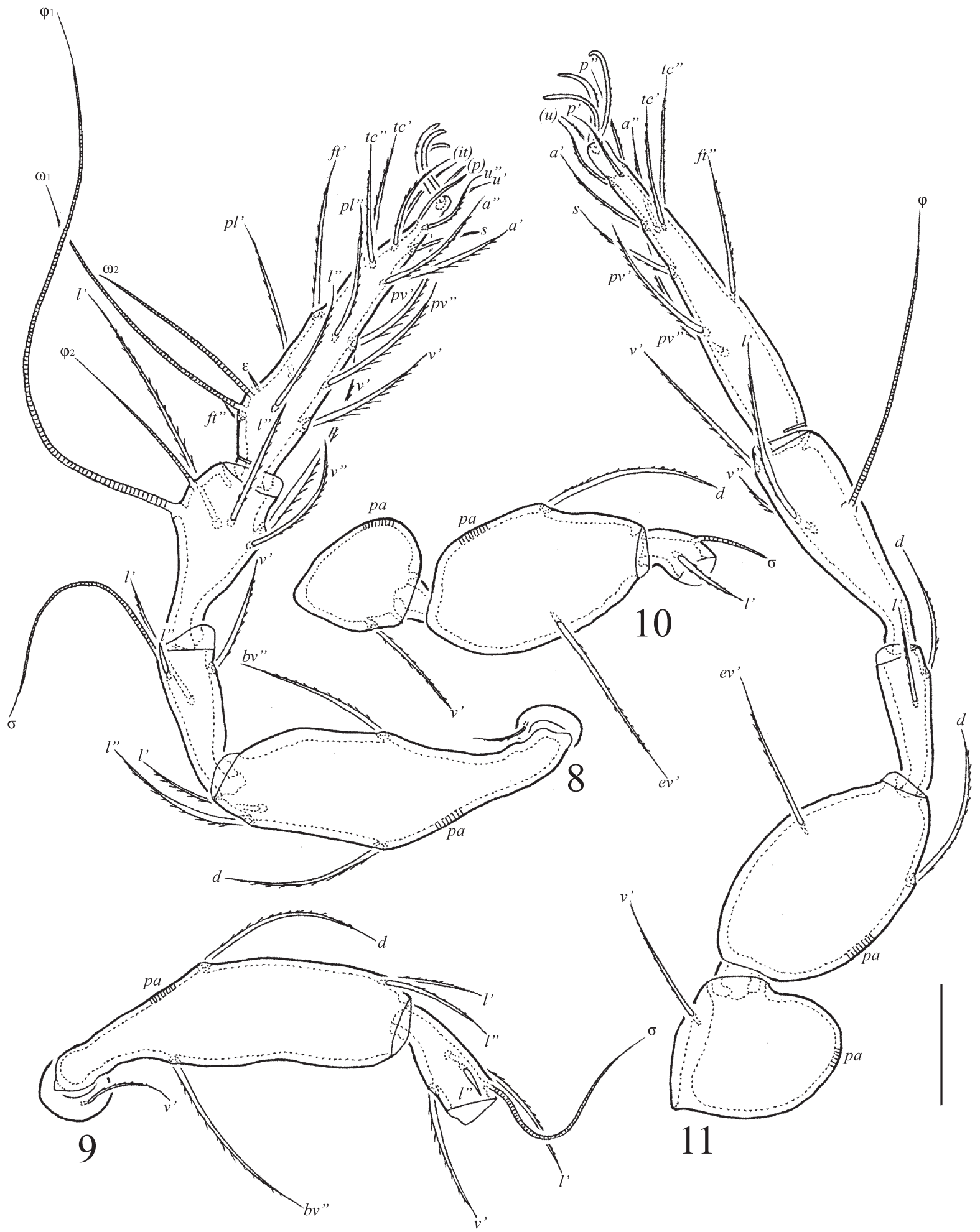

Figs. 8-11. Galumna (Galumna) paralawrencei sp.n., adult: 8-leg I, right, antiaxial view; 9-leg II, without tibia and tarsus, right, antiaxial view; 10-leg III, without tibia and tarsus, left, antiaxial view; 11—leg IV, left, antiaxial view. Scale bar $=50 \mu \mathrm{m}$.

28-32; $h, 24-28)$ and adoral (20-24) setae setiform, barbed. Length of palps: 123-127. Postpalpal setae (6) thorn-like. Length of chelicerae: 213-221. Cheliceral setae (cha, 69-73; chb, 49-53) setiform, barbed. Trägårdh's organ of chelicerae long, elongate triangular.

Epimeral and lateral podosomal regions (Figs. $2,3)$. Anterior tectum of epimere I smooth. Epim- 
eral setal formula 1-0-1-2. Epimeral setae setiform, barbed; $3 b$ (41-45) longer than $1 b$ (32-36), $4 a$ and $4 b$ (20-24). Pedotecta I and II rounded in ventral aspect. Discidia triangular in ventral aspect. Circumpedal carinae of medium size, thin, directed to insertions of epimeral setae $3 b$ but not reaching them.

Anogenital region (Figs. 2-5). Six pairs of genital $\left(g_{1}, g_{2}, 28 ; g_{3}-g_{6}, 20\right)$, one pair of aggenital (20-24), two pairs of anal (24-28) and three pairs of adanal (32) setae setiform, barbed. Anterior edge of genital plates with two setae. Aggenital setae located between genital and anal apertures, closer to the former. Adanal lyrifissures located close and diagonal to posterior half of anal plates. Adanal setae $a d_{1}$ and $a d_{2}$ posterior, $a d_{3}$ lateral to anal plates. Unpaired postanal porose area oval $(49-53 \times 28$ $32)$. Ovipositor elongated $(356 \times 49)$, blades $(172)$ shorter than length of distal section (beyond middle fold; 184). Each of the three blades with four smooth setae, $\psi_{1} \approx \tau_{1}$ (69) setiform, $\psi_{2} \approx \tau_{\mathrm{a}} \approx \tau_{\mathrm{b}} \approx \tau_{\mathrm{c}}$ (32) thorn-like. Coronal setae (8) thorn-like.

Legs (Figs. 8-11). Median claw slightly thicker than lateral claws, all barbed on dorsal sides. Porose area on all femora and on trochanters III, IV poorly visible. Formulas of leg setation and solenidia: I (1-4-3-4-20) [1-2-2], II (1-4-3-415) $[1-1-2]$, III (1-2-1-3-15) [1-1-0], IV (1-2$2-3-12)[0-1-0]$; homologies of setae and solenidia indicated in Table 1. Famulus on tarsi I inserted anterolaterally to solenidion $\omega_{2}$. Solenidion on tibiae IV inserted in anterior part of the segment.

Material examined. Holotype (male) and three paratypes (two males and one female): South Africa, near Cookhouse, next to road near railway, Eastern Cape, $33^{\circ} 05.140 \mathrm{~S}, 25^{\circ} 51.380 \mathrm{E}$, dry soil and decomposed leaf litter underneath Rhus sp., V.1982, collected by C.M. Engelbrecht (Museum No. NMB 2079.1).

Type deposition. The holotype is deposited in the collection of the National Museum Bloemfontein, South Africa (NMB 2079.1.1). Three paratypes are deposited in the collection of the Tyumen State University Museum of Zoology, Tyumen, Russia. All specimens are preserved in ethanol with a drop of glycerol.

Etymology. The specific name paralawrencei refers to the similarity between the new species and Galumna lawrencei Jacot, 1940.

Remarks. Galumna (Galumna) paralawrencei sp.n. is morphologically most similar to Galumna (Galumna) lawrencei Jacot, 1940 from South Af- rica (see Jacot 1940; Ermilov and Hugo-Coetzee 2019) in the presence of dorsosejugal suture, median pore, setiform bothridial setae, four pairs of notogastral porose areas with elongate triangular $A a$, and short interlamellar setae, but differs from the latter by the larger body size $(780-830 \times 581-647$ versus $680-747 \times 514-547)$, the localization of adanal lyrifissures (diagonal, located close to posterior half of anal plates versus longitudinal, located close to anterior half of anal plates), and the presence of hump-like structure in anterior part of prodorsum (versus absent) and distinctly longer notogastral porose areas $A a, A 2, A 3$ and anal and adanal setae.

\section{GENERAL REMARKS}

The systematic placement of Galumna ( $\mathrm{Ga}$ lumna) paralawrencei sp.n. as Galumna is tentative, since it has thickened lamellar lines, which are characteristic of representatives of the genus Carinogalumna Engelbrecht, 1973. However, we include the new species in the genus Galumna because the lamellar lines are thickened (relatively broadened), but visually not costula-like, as in Carinogalumna. Additionally, lamellar setae are located between the lamellar and the sublamellar lines (vs. being medial to lamellar lines or close to their ends in Carinogalumna).

\section{ACKNOWLEDGEMENTS}

The study was funded by the Russian Foundation for Basic Research (research project No. 1804-00096).

\section{REFERENCES}

Balogh, J. 1960. Oribates (Acari) nouveaux d'Angola et du Congo Belge (2 $2^{\text {ème }}$ série). Companhia de Diamantes de Angola, Lisboa, 51: 15-40.

Engelbrecht, C.M. 1969. Some South African species of the genus Galumna Von Heyden, 1826 (Acari: Galumnidae). Journal of the Entomological Society of Southern Africa, 32(1): 99-122.

Engelbrecht, C.M. 1972. Two new species of the genus Galumna von Heyden, 1826 (Galumnidae: Oribatei) from South Africa. Navorsinge van die $\mathrm{Na}$ sionale Museum, Bloemfontein, 2(9): 244-262.

Ermilov, S.G. and Hugo-Coetzee, E. A. 2019. Redescriptions and species status of the South African mites Galumna lawrencei Jacot, 1940 and Galumna natalensis Jacot, 1940 (Acari, Oribatida, Galumnidae), with lectotype designation. Zootaxa, 4568(3): 581-586.

Ermilov, S. G. and Hugo-Coetzee, E.A. 2020. Galumna capensis dissimilis Engelbrecht, 1969, a 
junior synonym of Galumna lawrencei Jacot, 1940 (Acari, Oribatida, Galumnidae), with remarks on type material. Zootaxa, 4750 (3): 441-442.

Ermilov, S.G., Hugo-Coetzee, E. A., Khaustov A.A. and Theron, P.D. 2017. New and interesting oribatid mites (Acari, Oribatida) near Potchefstroom (South Africa), with description of two new species. Systematic and Applied Acarology, 22(11): 1849-1871.

Ermilov, S.G. and Klimov, P. B. 2017. Generic revision of the large-winged mite superfamily Galumnoidea (Acari, Oribatida) of the world. Zootaxa, 4357(1): 1-72.

Ermilov, S.G., Hugo-Coetzee, E.A. and Theron, P.D. 2018. To the knowledge of oribatid mites of the sub- genus Galumna (Galumna) Heyden 1826 (Acari, Oribatida, Galumnidae) in South Africa, with a key to species known from the Ethiopian region. Zoologicheskii Zhurnal, 97(5): 515-527.

Heyden, C. von. 1826. Versuch einer systematischen Eintheilung der Acariden. Isis, Oken, 1(4): 607-613.

Jacot, A.P. 1940. New oribatid mites from South Africa. Annals of the Natal Museum, 9(3): 391-400.

Subías, L.S. 2020. Listado sistemático, sinonímico y biogeográfico de los ácaros oribátidos (Acariformes: Oribatida) del mundo (excepto fósiles). $15^{\text {a }}$ actualización. Online version accessed in January 2020, 527 pp.; http://bba.bioucm.es/cont/ docs/RO_1.pdf

Table 1

Leg setation and solenidia of Galumna (Galumna) paralawrencei Ermilov and Hugo-Coetzee sp.n.

\begin{tabular}{|l|l|l|l|l|l|}
\hline Leg & Tr & Fe & Ge & Ti & Ta \\
\hline I & $v^{\prime}$ & $d,(l), b v^{\prime}$ & $(l), v^{\prime}, \sigma$ & $(l),(v), \varphi_{1}, \varphi_{2}$ & $(f t),(t c),(i t),(p),(u),(a), s,(p v), v^{\prime},(p l), l^{\prime}, \varepsilon, \omega_{1}, \omega_{2}$ \\
\hline II & $v^{\prime}$ & $d,(l), b v^{\prime}$ & $(l), v^{\prime}, \sigma$ & $(l),(v), \varphi$ & $(f t),(t c),(i t),(p),(u),(a), s,(p v), \omega_{1}, \omega_{2}$ \\
\hline III & $v^{\prime}$ & $d, e v^{\prime}$ & $l^{\prime}, \sigma$ & $l^{\prime},(v), \varphi$ & $(f t),(t c),(i t),(p),(u),(a), s,(p v)$ \\
\hline IV & $v^{\prime}$ & $d, e v^{\prime}$ & $d, l^{\prime}$ & $l^{\prime},(v), \varphi$ & $f t^{\prime},(t c),(p),(u),(a), s,(p v)$ \\
\hline
\end{tabular}

Note: Roman letters refer to normal setae, Greek letters - to solenidia (except $\varepsilon=$ famulus), Single prime (') marks setae on anterior and double prime (") - setae on the posterior side of a given leg segment. Parentheses refer to a pair of setae. 